\title{
COMPARATIVE STUDY ON THE ACTIVE CHEMICAL CONSTITUENTS OF SOME CHENOPODIACEAE PLANTS
}

(Received: 29. 1. 2014)

\author{
By \\ A. E. Abozeed \\ Medicinal and Aromatic Plants Department, Desert Research Center, El-Matarya, Cairo, Egypt
}

\begin{abstract}
This study aimed to investigate and compare between the chemical constituents of some Chenopodiaceae plants (Beta vulgaris (Linn.), Bassia muricata (L.), Tragonum nudatum (Del.), Salvia lanigera (Poir.) and Salsola kali (L.) growing widely at Matruh habitat (North Western Coast Egypt) collected at the spring season of 2007-2008. Phytochemical screening of the aerial parts of the studied plants revealed some differences in the chemical constituents. Determination of water content, total soluble and insoluble carbohydrates, total nitrogen and protein contents, total lipids , total ash and the crude fibre content also revealed the presence of some differences in the values of these constituents between the five studied plants. On the other hand, the percentages of total flavonoids reached it's maximum value in Tragonum nudatum (Del.) and it's minimum value in Salvia lanigera (Poir.). The highest value of alkaloids was detected in Beta vulgaris (Linn. ), while the lowest value was detected in Salvia lanigera (Poir.). Saponins were most abundant in Tragonum nudatum (Del.). While, Salvia lanigera (Poir.) possessed the higher content of tannins than the other species. Moreover, all the studied plants contained high contents of $\mathrm{Na}, \mathrm{Ca}$ and $\mathrm{K}$ and very small amounts of $\mathrm{Ni}$ and $\mathrm{Cr}$. Phenolic and flavonoid compounds in the studied plants were determined by using paper chromatography and HPLC techniques. Tragonum nudatum (Del.) had the lowest water content, total carbohydrates and elements and high concentration of total proteins, flavonoids and phenolic compounds. The presence of alkaloids and flavonoids in all the plants, suggests their antioxidant potentials and justifies their therapeutic actions, which could be used in drug formulation. The presence of tannin in all the investigated plants indicated that they could be used in the treatment of burns and wounds.
\end{abstract}

Key words: alkaloids, carbohydrates, chenopodiaceae, phenolic and flavonoid compounds, phytochemical screening, saponins.

\section{INTRODUCTION}

The active chemical constituents are compounds that occur naturally in plants. They contribute to the color, flavor and smell of plants. In addition, they form part of a plant's natural defense mechanism against diseases. Their therapeutic values to human health and disease prevention have been reported (Okwu, 2004).

Family chenopodiaceae is characterized by the presence of 102 genera and about 1400 species ( Pandy, 1982 ). It contains numerous species which vary greatly in their chemical constituents and uses such as alkaloids, flavonoids, saponins and tannins.

Approximately 1300 species of chenopods (family: Chenopodiaceae) worldwide range from annual herbs to trees. Many species of chenopods are allocated among $\mathrm{C} 4$ photosynthesis plants. The flowers are tiny and inconspicuous, but some species bear showy masses of fruits. Chenopods are common in deserts and especially in saline or alkaline soils (Houerou et al., 1995).

Many plants of this family are used in folk medicine as antimicrobial remedies, where crude preparation of such plants are used in different forms for oral and external local applications to throat microbial infections. Beta vulgaris (Linn.) is a native of south Europe, extensively cultivated as an article of food and especially for the production of sugar, it pacifies vitiated vata, pitta, urinary retention,anemia, inflammation, liver and spleen diseases, amenorrhea, dysmenorrheal and general debility.

Two acylated flavonoid glycosides (Caffeoyl 
and Feruloyl) have been isolated from the aerial parts of Bassia muricata (Mohamed et al., 2001).

A new natural methyl ester of carnosic acid isolated from the arial parts of Salvia lanigera (Hassan,1985), was shown to contain oleanolic and ursolic acids (Abedl-moneim et al., 1967). Chloroform extract of the roots of the Egyptian Salvia lanigera Poir. afforded two new orthoquinones, Lanigerone and Salvigerone together with two known diterpenoids ,aurcadiol and pisiferal (Lee et al., 1998)

According to Hartwell (1967-1971), the plants of Salsola kali L. are used in folk remedies and to be cathartic, diuretic, emmenagogue, poisonous, stimulant, and vermifuge. Russian thistle is a folk remedy for dropsy and excrescence (Duke and Wain, 1981). Navaho used a decoction of the ashes, both internally and externally for influenza and smallpox (Duke, 1983).

Salsola kali L. contains oxalic acid and excess of $\mathrm{KNO}_{3}$, so it may be toxic to grazing animals. We selected five plants of the family chenopodiaceae to compare their constituents of active materials.

\subsection{Source of Materials \\ 2. MATERIALS AND METHODS}

Beta vulgaris (Linn.), Bassia muricata (L.), Tragonum nudatum (Del.), Salvia lanigera (Poir.) and Salsola kali (L.) growing widely at Matruh habitat (North Western Coast, Egypt). The aerial parts of the studied plants were collected during the spring season of 2007-2008.

The plants obtained from this region were identified and separately prepared for chemical analysis.

2.2. Methods

\subsubsection{Determination of constants and other constituents}

Water content, the total ash content, acid and water insoluble ash and the crude fibre contents were determined according to Alabi et al. (2005). The total soluble and insoluble carbohydrates were determined according to Chaplin and Kennedy (1994). The total nitrogen and protein contents were determined according to James( 1995 ) and the total lipids were determined according to Christie (1982).

\subsubsection{Active constituents}

2.2.2.1. Preliminary photochemical screening

The qualitative determination of tannins, sterols, carbohydrates and/or glycosides, flavonoids, phenolics, alkaloids, saponins and resins in ethanolic extracts of the studied plants were performed according to the method of Woo et al. (1977), Sofowara. (1993), Mojab et al. (2003), Edeoga et al. (2005) and Edeoga et al. (2006).

\subsection{Determination of the active constituents}

2.3.1. Determination of total flavonoids

The total flavonoids were determined by spectrophotometerically method described by Karawya and Aboutable (1982).

\subsubsection{Determination of total alkaloids}

The total alkaloids were estimated using two methods the acid- base titration and the gravimeteric methods as described by Balbaa (1986) and Woo et al., (1977)

\subsubsection{Determination of total saponin}

Saponin content of the studied plants were determined according to Balbaa (1986).

\subsubsection{Determination of total tannins}

The total tannins were estimated according to Makkar and Googchild method (1996).

\subsection{Phytochemical screening by using successive extraction}

Five grams from each of the air dried powdered samples of the five studied plants were successively extracted in a Soxhlet with petroleum ether (b.p.40 to $60^{\circ}$ ), ether, chloroform, benzene, acetone, alcohol $80 \%$ and water. Phytochemical screening was carried out for each extract of the five plants as mentioned before .

\subsection{Element measurements}

Sodium and potassium were determined in the digested samples of the studied plants using a flame photometer according to Allen (1989). Phosphorus content in the digested samples was determined colorimetrically by the molybdic acid method as described by Humphries (1956). The contents of $\mathrm{Ca}^{++}$were determined using Unicam 929 atomic absorption spectrophotometer.

2.6. Isolation of phenolic and flavonoid compounds using paper chromatography

Each methanolic extract of the plant species was separately chromatographed on Whatman No.1 paper chromatography along side with the available authentic samples using the solvent system n-butanol: acetic acid: water $(4: 1: 5, \mathrm{v} / \mathrm{v} / \mathrm{v})$ for the first way and the solvent system acetic acid water ( $15: 85 \mathrm{v} / \mathrm{v}$ ) for the second way. The developed chromatograms were air dried, and examined under ultraviolet (UV) light. The concentrated ethanolic extracts of the plant species were applied separately on the top of a cellulose column. Elution was started with water 
followed by a mixture of water /methanol and finally pure methanol was used. The received fractions were evaporated and similar fractions were collected together, evaporated and subjected to paper chromatography (Liu et al., 1989). Preparative paper chromatography was applied on Whatman No.3 paper chromatography using the solvent system BAW. The separated flavonoid and phenolic compounds were purified on a sephadex LH-20 column using methanol / water system. Carboxylic acids, hydroxy flavonoids and sugars were detected by spraying the air dried chromatograms with different reagents

\subsection{Phenolic and flavonoid compounds using HPLC}

Phenolic and flavonoid compounds of the five selected plants were detected by using high performance liquid chromatography (HPLC) according to Ben-Hammouda et al. (1995).

\section{RESULTS AND DISCUSSION}

\subsection{Determination of constants and other constituents}

It is clear from Table (1) that, the mean values of water content were 26.82,15.21, $11.23,18.62$ and $14.18 \%$ for the studied species (Beta vulgaris, Bassi muricata, Traganum nudatum, Salvia lanigera and Salsola kali, respectively).

Mohamed and Alain (1995) suggested the accumulation of carbohydrates under salinity stress is due to a reduction in their utilization , either as a source of energy or for the formation of new cells and tissues. The present data indicated that the percentages of water content, total, soluble and insoluble carbohydrates of $B$. vulgaris were higher than the other species. The total nitrogen and crude protein content of $T$. nudatum were 1.69 and $10.56 \%$ and they were higher than the other species. The total lipid content of B.muricata reached its maximum value of $3.46 \%$ and its minimum value of $1.50 \%$ in $S$. kali. Total ash content of T..nudatum was higher than the other species, while the acid - insoluble ash was the lowest in the same plant. Water - insoluble ash content of the studied species reached its maximum value of $12.50 \%$ in S.lanigera. Al- Owaimer et al. (2008). reported that ash contents were16.61 and $16.42 \%$ for Atriplex halimus and A. lecucoclada, respectively. Meanwhile Rizk (1986) reported that Schanginia aegyptiaca of family Chenopodiaceae contained a very high ash content $(39.82 \%)$. This reflects the particular origin of the plant which grows on salinized soil. Table (1) showed that, B. muricata had the maximum value of crude fibre content (14.82 $\%)$.

The results presented in Table (1) showed that, there is an inverse relationship between water content and the crude fibre contents.

\subsection{Active constituents}

\subsection{1. preliminary phytochemical screening}

Table (2) showed that, tannins, sterols, carbohydrates and / or glycosides, flavonoids, phenolics and alkaloids were detected in all the studied species, (saponins were detected only in B.muricate, T.nudatum and S.kali). While the resins were present in T.nudatum as traces and S.lanigere and absent in the other species. The presence of these active constituents in the studied plants account for its usefulness as medicinal plants.

\subsubsection{Determination of the active onstituents}

Flavonoids are potent water soluble antioxidants and free radical scavengers which prevent oxidative cell damage. They have strong anticancer activity and protect against the different levels of carcinogenesis (Okwu, 2004). Flavonoids in the intestine lower the risk of heart diseases. The antioxidant potentials of the plants have been linked with their flavonoid contents. In addition, the therapeutic potentials of plants have been linked with their antioxidant potentials (Akinmalodun et al., 2007; Eleazu et al., 2011). As antioxidants, the flavonoids from these plants may provide anti-inflammatory activity. Thus the high alkaloid and flavonoid contents of these plants explain their therapeutic use in herbal medicine especially in the treatment of wounds, burns and ulcers.

Data presented in Table (3) indicated that, less concentrations of total flavonoids were detected only in S. lanigera (1.10\%), while the high concentration was observed in Tragonum nudatum $(2.83 \%)$.

Alkaloids are basic natural products occurring primarily in plants. They occur as one or more heterocyclic nitrogen atoms and are generally found in the form of salts with organic acids. Alkaloids are the most efficient therapeutically significant plant substances. Pure isolated alkaloids and their synthetic derivatives are used as basic medicinal agents because of their analgesic, antispasmodic and anti-bacterial properties (Stray, 1998). Table (3) showed that, alkaloids high concentration was detected in B.vulgaris $(3.65 \%)$ and the lowest concentration in S.lanigera $(0.63 \%)$. 
Table (1): Mean values of different constants and constituents of the studied species.

\begin{tabular}{|c|c|c|c|c|c|}
\hline Constants and constituents & $\mathbf{1}$ & 2 & 3 & 4 & 5 \\
\hline Water content & 26.82 & 15.21 & 11.23 & 18.62 & 14.18 \\
\hline Total carbohydrates & 3.48 & 1.16 & 1.07 & 2.96 & 1.86 \\
\hline Soluble carbohydrates & 2.32 & $\mathbf{0 . 8 5}$ & 0.79 & 2.02 & 1.14 \\
\hline Insoluble carbohydrates & 1.16 & 0.31 & 0.28 & 0.94 & 0.72 \\
\hline Total nitrogen content & 0.94 & 0.76 & 1.69 & 1.51 & $\mathbf{0 . 8 0}$ \\
\hline Crude protein content & 5.83 & 4.73 & 10.56 & 9.44 & 4.98 \\
\hline Total lipid content & 2.58 & 3.46 & 2.06 & 2.90 & $\mathbf{1 . 5 0}$ \\
\hline Total ash content & 17.16 & 14.06 & 22.60 & 12.97 & 15.79 \\
\hline Acid -insoluble ash & 2.92 & 3.52 & 1.96 & 3.91 & 3.30 \\
\hline Water -insoluble ash & 11.06 & 9.07 & 7.86 & 12.50 & 7.48 \\
\hline Crude fibre content & 9.82 & 14.82 & 11.56 & 8.90 & 11.26 \\
\hline
\end{tabular}

Table (2): Preliminary phytochemical screening.

\begin{tabular}{|c|c|c|c|c|c|}
\hline Tests & 1 & 2 & 3 & 4 & 5 \\
\hline Tannins & +++ & ++ & ++ & +++ & ++ \\
\hline Sterols & ++ & ++ & ++ & +++ & + \\
\hline Flavonids, phenolics & ++ & +++ & +++ & ++ & +++ \\
\hline Alkaloids & +++ & + & ++ & + & + \\
\hline $\begin{array}{lc}\text { 1- Beta vulgaris } & \text { 2- Bassia muricata } \\
\text { 4- Salvia lanigera } & \text { 5- Salsola kali } \\
\text { - traces + positive } & ++ \text { moderately p }\end{array}$ & itive & raganun & & & \\
\hline
\end{tabular}

Table (3): Percentage of the active constituents of the five selected plants.

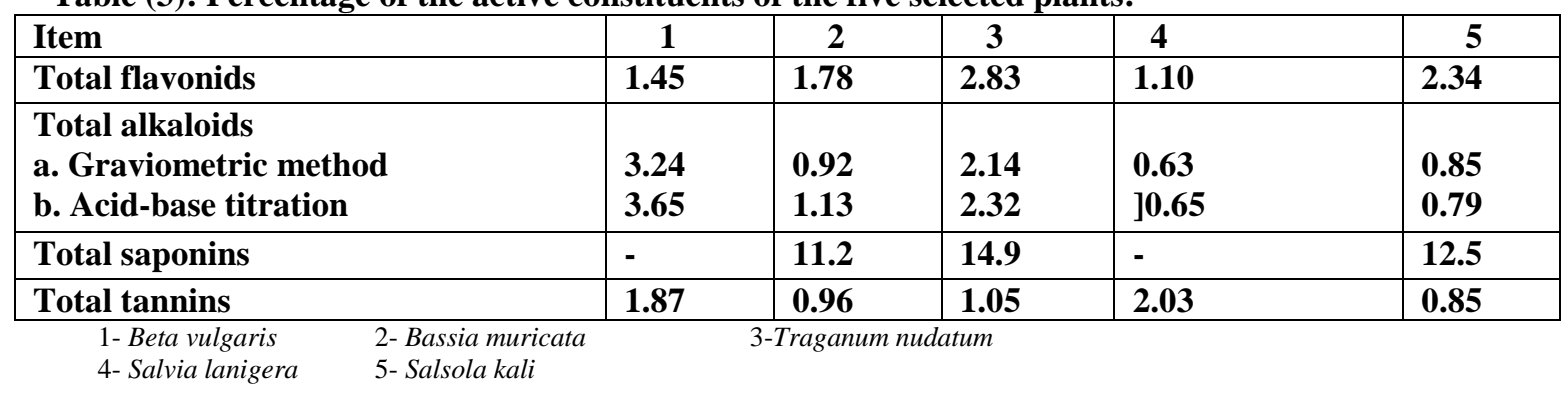


Saponin has the property of precipitating and coagulating red blood cells. Some of the characteristics of saponins include formation of foams in aqueous solutions, hemolytic activity, cholesterol binding properties (Eleazu et al., 2010) and bitterness (Sodipo et al., 2000). Saponins were present only in B.muricate, T.nudatum and S.kali, (11.2, 14.9 and $12.5 \%$ respectively).

Tannins are dietary anti-nutrients that are responsible for the astringent taste of foods and drinks (Chikezie et al., 2008). The tannin content of Salvia lanigera was significantly higher than the other plants studied while that of Salsola kali was the least.

The presence of flavonoids and tannins in the plants is likely to be responsible for the free radical scaveging effects observed. Flavonoids and tannins are phenolic compounds and plant phenolics are a major group of compounds that act as primary antioxidants or free radical scavengers (Poltrait, 1997).

\subsubsection{Phytochemical screening by using successive extraction}

It is clear from Table (4) that, flavonoids, alkaloids, saponins and tannins were absent by using petroleum ether extract, while alkaloids were present as traces in $S$. kali only by using ether extract. With chloroform extract ,alkaloids only were present in the five studied plants. Ethyl acetate extract revealed that the presence of flavonoids in all the studied plants, while alkaloids were present only in S.lanigera, saponins and tannins were present as traces in $B$. muricata, T.nudatum and S.kali and absence in B. vulgaris and S.lanigera.

Ethyl alcohol $96 \%$ and ethyl alcohol $70 \%$ extracts showed the absence of saponins in $B$. vulgaris and $S$. lanigera and present in the other plants, while flavonoids, alkaloids and tannins were present in the five species. Saponins and tannins were absent in $B$. vulgaris and $S$. lanigera and present in B.muricata, T.nudatum and S.kali, while flavonoids and alkaloids were present in all the studied plants by using the water extract as shown in Table (4).

\subsection{Elements measurements}

Table (5) presented the elements composition of the five studied plants. The data showed that, the maximum contents of $\mathrm{Na}, \mathrm{Ca}$, $\mathrm{Zn}$ were present in Salvia lanigera. Also, the maximum contents of $\mathrm{K}, \mathrm{Mn}$ were recorded in Beta vulgaris. Bassia muricata contained higher contents of $\mathrm{P}, \mathrm{Fe}, \mathrm{Al}$ and $\mathrm{Cu}$ than the other species. All the studied plants contained very small amounts of $\mathrm{Ni}$ and $\mathrm{Cr}$.

Saltbushes, in general, are characterized by moderate crude protein and high mineral contents, particularly $\mathrm{Na}, \mathrm{K}, \mathrm{Cl}$ and $\mathrm{Ca}$ concentrations. Potassium is an important contributor to the osmotic potential of the cells while calcium is an important mineral for the constructions of cell walls (Pessarakli, 1995). The reduction of phosphate concentration in stressed plants is due to its unavailability in the soil. Several studies have been conducted regarding the utilization of saltbushes in animal feeding (El Shaer et al., 1987).

\subsection{Phenolic and flavonoid compounds using paper chromatography}

Table (6) revealed the presence of rutin, myricetin, qurcetin, kaempferol and Kaempferol-3-O -a-L-rhamnoside with different concentrations in the all studied species, isorhamnetin and isorhamnetin 3- o-rutinoside were present only in two plants ( T. nudatum and S. kali ), while isorhamnetin 3-o-glucoside was present only in S.kali .Also chlorogenic acid was present only in $T$. nudatum and $S$. lanigera, gallic acid was absent in $S$. lanigera and present in the other species, ferulic acid was absent in $T$. nudatum and S. kali and present in the others. Kaempferol -3-o-B-D-glucoside was present with different concentrations in B. vulgaris, T.nudatum and S.kali and absent in the two other plants, Qurcetin $3^{-} \mathrm{O}^{-} \alpha^{-} \mathrm{L}-$ rhamnoside was absent in T.nudatum and present in the other species, while Qurcetin -3-O-B-D- glucoside was present in B.muricata, T.nudatum, S.lanigera and S.kali and absent in B.vulgaris as shown in Table (6).

\subsection{Phenolic and flavonoid compounds using HPLC}

Flavonoids are important dietary compounds, having a capacity to inhibit DNA damage and lipid peroxidation and quench free radicals. They also have anti-carcinogenic and antiproliferative effect (Romanova and Vachalkova, 1999). Some flavonoids act as growth regulators, phytoalescenins,nimal toxins and sweating agents while others have estrogenic action, reduce capillary fragility and employed as genetic markers. Phenolic compounds were found to be highly toxic to certain protozoa (Watt and Breyer Brandoijk, 1962). Quercetin had the maximum value of phenolic and flavonoid compounds in B.muricata while $P$ catechiuc acid had the minimum value in S.lanigera as shown in Table (7). 
Table (4): Phytochemical screening for the five selective plants by using successive extraction.

\begin{tabular}{|c|c|c|c|c|c|c|c|c|c|c|c|c|c|c|c|c|c|c|c|c|}
\hline \multirow[t]{3}{*}{ Solvent } & \multicolumn{20}{|c|}{ Active materials } \\
\hline & \multicolumn{5}{|c|}{ Flavonoids } & \multicolumn{5}{|c|}{ Alkaloids } & \multicolumn{5}{|c|}{ Saponins } & \multicolumn{5}{|c|}{ Tannins } \\
\hline & 1 & 2 & 3 & 4 & 5 & 1 & 2 & 3 & 4 & 5 & $\mathbf{1}$ & 2 & 3 & 4 & 5 & 1 & 2 & 3 & 4 & 5 \\
\hline P. ether & - & - & - & - & - & - & - & - & - & - & - & - & - & - & - & - & - & - & - & - \\
\hline Ether & - & - & - & - & - & - & - & - & - & \pm & - & - & - & - & - & - & - & - & - & - \\
\hline Cholroform & - & - & - & - & - & +++ & + & ++ & + & + & - & - & - & - & - & - & - & - & - & - \\
\hline Ethyl acetate & + & \pm & ++ & + & + & - & - & - & +- & - & - & \pm & + & - & + & - & \pm & \pm & - & \pm \\
\hline $\begin{array}{l}\text { Ethyl alcohol } \\
96 \%\end{array}$ & + & ++ & ++ & + & ++ & ++ & ++ & ++ & + & ++ & - & + & ++ & - & ++ & +++ & ++ & ++ & +++ & ++ \\
\hline $\begin{array}{l}\text { Ethyl alcohol } \\
70 \%\end{array}$ & ++ & +++ & +++ & ++ & ++ & +++ & ++ & +++ & + & ++ & - & ++ & ++ & - & ++ & ++ & + & + & ++ & ++ \\
\hline Water & + & ++ & + & + & ++ & + & + & ++ & + & ++ & - & ++ & + & - & ++ & - & ++ & ++ & - & + \\
\hline $\begin{array}{l}\text { +- pos } \\
++ \text { mo } \\
\text { 1- Bet } \\
\text { 4- Sal }\end{array}$ & $\begin{array}{l}\text { vulg } \\
\text { a lar }\end{array}$ & $\begin{array}{l}\text { nega } \\
\text { ly pos } \\
\text { is } \\
\text { gera }\end{array}$ & $2-$ & assia & uric & & & $\begin{array}{l}+\mathrm{w} \\
+++ \\
3-T \\
5-\end{array}$ & $\begin{array}{l}a g c \\
\text { alsc }\end{array}$ & kali & сти & & & & & & & & & \\
\hline
\end{tabular}

Table (5): Elements composition of the studied plants.

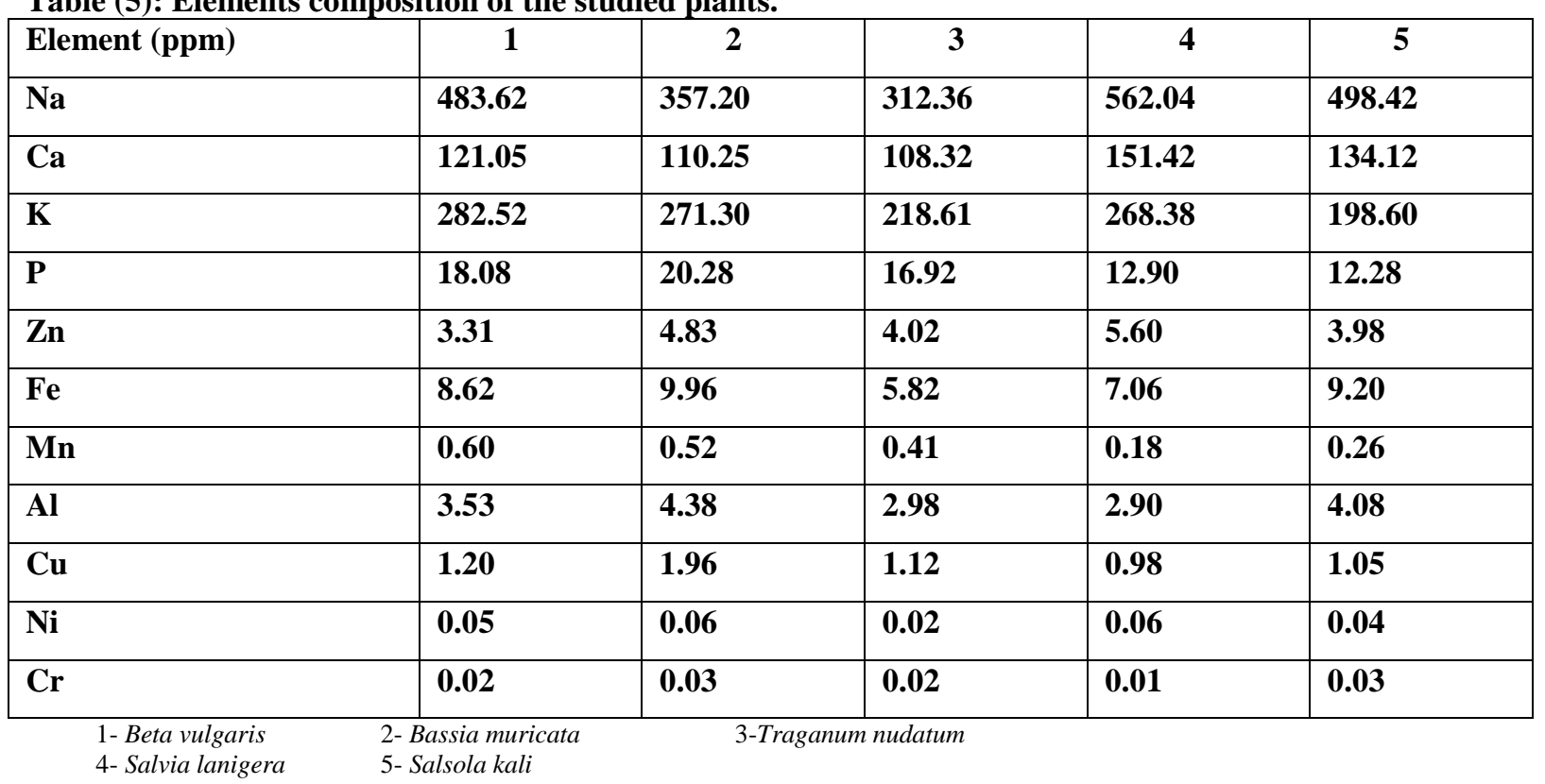


Table (6): Phenolic and flavonoid compounds of the five selected plants using paper chromatography.

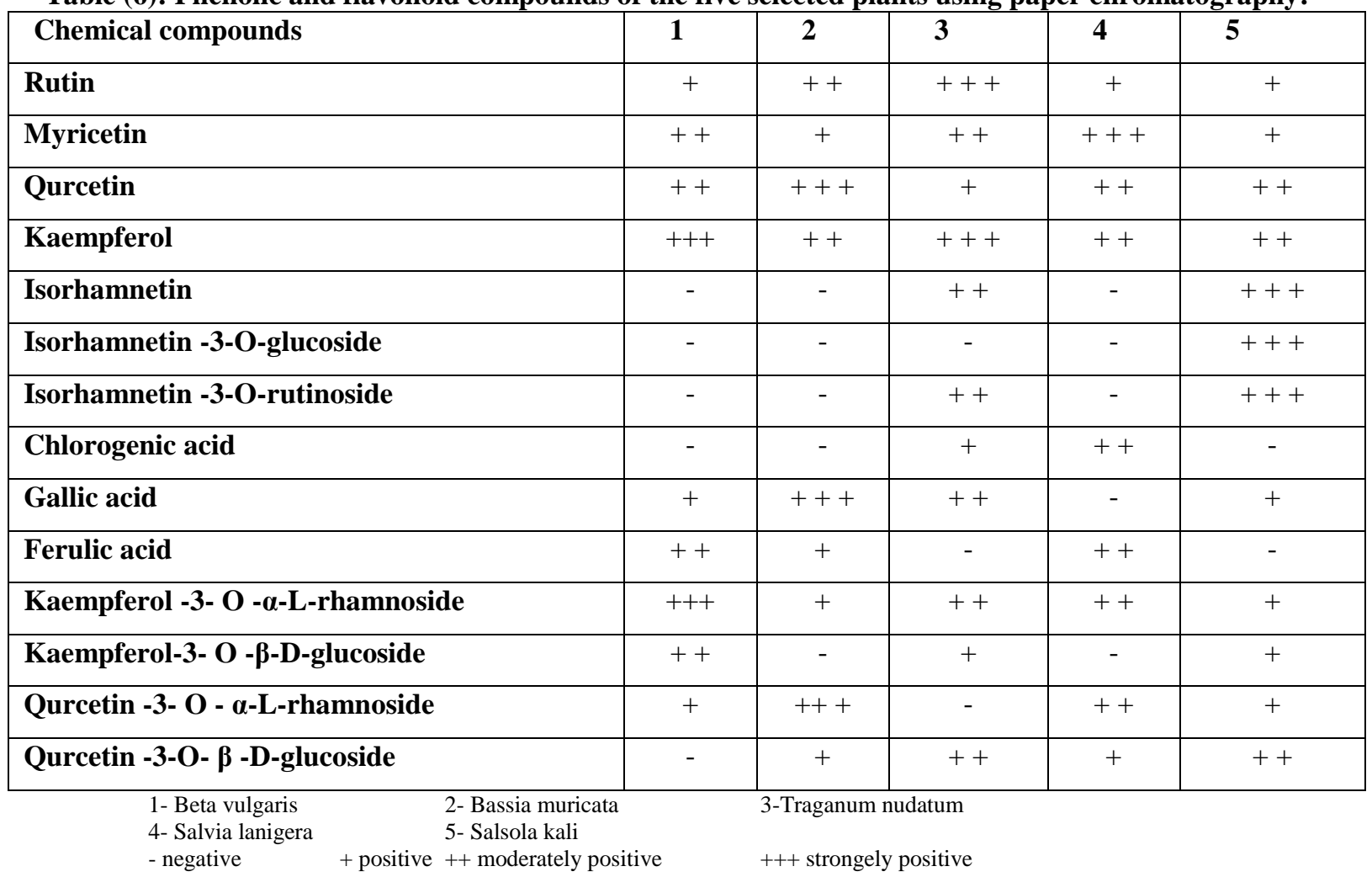

Table (7): Phenolic and flavonoid compounds of the five selected plants using HPLC.

\begin{tabular}{|c|c|c|c|c|c|}
\hline \multirow[t]{2}{*}{ Compounds } & \multicolumn{5}{|c|}{ Phenolic and flavonoids $\mu \mathrm{g} / \mathrm{g}$} \\
\hline & 1 & 2 & 3 & 4 & 5 \\
\hline$P$ - catechuic acid & - & 3.59 & 0.96 & 0.13 & 4.03 \\
\hline Chlorogenic acid & - & - & 1.85 & 4.27 & - \\
\hline Catechum & 0.46 & 1.27 & 7.31 & 0.68 & 5.52 \\
\hline Salicylic acid & 1.49 & 0.16 & - & 0.07 & - \\
\hline$P$ - coumaric acid & 0.38 & 2.19 & 5.95 & - & 7.36 \\
\hline Rutin & 2.62 & 8.52 & 13.73 & 2.09 & 3.84 \\
\hline Ferulic acid & 5.09 & 0.67 & - & 3.26 & - \\
\hline Coumarin & 1.06 & 4.28 & 6.57 & - & 8.02 \\
\hline Myricetin & 10.74 & 1.89 & 9.10 & 27.63 & 1.56 \\
\hline Quercetin & 15.32 & 38.62 & 8.15 & 19.07 & 11.53 \\
\hline Kaempferol & 28.07 & 10.26 & 17.63 & 15.08 & 9.83 \\
\hline Isorhamnetin & - & - & 22.35 & - & 35.64 \\
\hline $\begin{array}{c}\text { 1- Beta vulgaris } \\
\text { 4- Salvia lanigera }\end{array}$ & $\begin{array}{l}\text { muricata } \\
\text { kali }\end{array}$ & & num nuda & & \\
\hline
\end{tabular}


The flavonoid compounds and phenolic acids, which were separated from these five selected plants are important in medicine such as:

1- Rutin can use as antioxidant, inhibitory for the adenosine deaminaze, inhibitory for lens aldose reductase, antilipoperoxidant, antihepato toxic and for expansion of the artery (Sigma, 1992 and Balbaa et al, 1981)

2- Myrecetin can be used as antioxidant, while phenolic myrecetin and gallic acid support healthy functions ol the cardiovascular system, beside supporting health cells and other components ol the human organism.

3- Kaempferol can be used as antioxidant .

4- Quercetin can be used as antioxidant and as an inhibitor ol protein tyrosine kinases (Sigma, 1992).

5- Chlorogenic acid has high antioxidant capacity, significantly higher than any other natural antioxidant and about five times higher than vitamin $\mathrm{C}$ in the juice of apple.

\section{Conclusion}

The obtained results showed that, all the studied plants contained high quantities of alkaloids and flavonoids suggesting their antioxidant potentials and justifying their therapeutic uses which could be utilized in drug formulation. Finally, the low quantities of tannin in all the plants studied suggest that usage of these plants in herbal medicine can neither interfere with dietary iron absorption nor inhibit digestive enzymes.

\section{REFERENCES}

Abdel-Moneim F. M, Elgamal M. H. A, Fayez M. B. A and Salam L. A. R (1967). Phytochemistry, volume 6, Issue 7, Jully 1967, Pages 1035-1036.

Akinmalodun A.C., Ibukun E.O., Afor E., Akirinlola B.L., Onibon T.R., Akinboboye A.O., Obuotor E.M. and Farombi E.O. (2007). Chemical constituents and antioxidant activity of Alstonia boonei. Afr. J. Biotechnol., 6 (10): 1197-1201.

Alabi D. A., Akinsulire O.R. and Sanyaolu M. A. (2005). Qualitative determination of chemical and nutritional composition of Parkia biglobosa (Jacq) Benth. Afri. J. of Biotechnol., 4(8): 812-815.

Allen S.E. (1989). Chemical Analysis of Ecological Materials. Oxford, Blackwell Scientific Puplications, pp368.

Al-Owaimer A.N., Zahran S.M. and AL-Bassam B. A. (2008). Effect of feeding some types of Atriplex spp. in complete diet on growth performance and digestibility of growing lambs. Res. Bult., No. (161), Food Sci. \& Agric. Res. Center, King Saud Univ., p.5-19.

Balbba S. I. (1986). Chemistry of Crude Drugs Laboratory Manual. Faculty of pharmacy, Cairo Univ., Egypt. pp195.

Balbba S. I., Hilal S. H. and Zaki A.Y. (1981). Medicinal plant constituents, $3^{\text {rd }}$ Ed. General Organization for Univ. Books, Cairo, Egypt. 644 pp.

Ben-Hammouda M., Kremer R.J., Minor H.C. and Sarwar M . (1995). A chemical basis for differential allelopathic potential of Sorghum hybrid on wheat. J. Chem. Ecol., 21:775-786.

Chaplin M. F. and Kennedy J. F. (1994). In "Carbohydrate analysis: A practical approach". Oxford University press. USA (Pub.) p 31-32 .

Chikezie P. C., Agomuo E. N. and Amadi B.A. (2008). Biochemistry, Practical/Research Method, A Fundamental Approach. Vol 2, Mega soft publishers, pp. 51-53.

Chrisitie W. W. (1982). Lipid Analysis. $2^{\text {nd }}$ Edition, Pergamon Press, pp 207.

Duke J.A. (1983). American medicinal plants. Type Script.

Duke J. A and Wain K. K. (1981). In Medicinal plants of the world. computer index with more than 85,000 entires. Vol 3 .

Edeoga H., Okwu D. and Mbaebie B. (2005). Phytochemical constituents of some Nigerian medicinal plants. Afri. J. of Biotechnol., 4(7): 685-688.

Edeoga H. O., Omosun G. and Uche L.C. (2006). Chemical composition of Hyptis suaveolens and Ocimum graissimum hybrids from Nigeria. Afri. J. of Biotechnol. 5 (10): 892- 895.

Eleazu C.O., Okafor P.N. and Ahamefuna I. (2010). Total antioxidant capacity, nutritional composition and inhibitory activity of unripe plantain (Musa paradisiacae) on oxidative stress in Alloxan induced diabetic rabbits. Pakistan J. Nutrition, 9 (11): 1052-1057.

Eleazu C.O., Okafor P.N., Amajor J., Awa E., Ikpeama A. I. and Eleazu K.C. (2011). Chemical Composition, antioxidant activity, functional properties and inhibitory action of unripe plantain $(M$. paradisiacae) flour. Afr. J. Biotechnol., 10 (74): 6948-6952. 
El Shaer E. M., Rammah A., Nasr A and Bayoumi M.T. (1987). Nutritional quality of some grasses in North Sinai. Proceedings of the $2^{\text {nd }}$ Int. Conf. Desert Develo., January 25-30. Cairo, Egypt.

Hartwell J. L. (1967-1971). Plants used against cancer. A survey. Lloydia 30-34.

Hassan M. G. (1985). Departement of chemistry, College of science, King Saud University, Saudi Arabia.

Houerou H.N.K., Le Houerou H.N., Choukr Allah R., Malcolm C.V. and Hamdy A. (1995). Forage halophytes in the Mediterranean Basin. Halo. And Bio. Agri., 115-136.

Humphries E.C. (1956). Mineral Composition and Ash analysis. In Modern Methods of Plant Analysis. ( Peatch, K. and Tracey, M.V., Eds.) 1,148, Springer, Verlage, Berlin.

James C. S. (1995). Analytical Chemistry of Foods. Blackie academic and professional publisher, an Imperin of Chapman and Hall, p 178.

Karawya M. S. and aboutable E. A. (1982). Phytoconstituentes of tabernaemontana cormaria Jac. Q.willed and dichotoma roxii B.growing in Egypt. the flavonoid. bulletin of faculty of pharma, Cairo univ., 21 (1): 41- 49.

Lee I. S., Kaneda N., Suttisri R., El-Lakany A. M., Sabri N. N., Kinghorn A. D.(1998). New orthoquinones from the roots of Salvia lanigera. Planta Med. 64 (7):632-4.

Liu Y. L., Neuman P., borbara N. I. and Mabry J. J. (1989). Techniques for flavonoids analysis Rev. latinamet. quim. suppl.1: 90-130.

Makkar H. P. S and googchild A.V. (1996) quantification of tannins: a laboratory manual. International Center Agricultural Research in the Dry Areas, Aleppo, Syria. Vol. 4, pp 25.

Mohamed N. and Alain C. (1995). Effects of sodium chloride on growth, tissue elasticity and solute adjustment in two Acacia nilotica sub-species. Physiol. Plant, 93:217-224.

Mohamed S. K., khaled M. M., Hashim A. h., kazuhiro o., ryoji k. and kazuo y. (2001). $\mathrm{x}$ Bassia muricata department of pharmacogonosy, faculty of pharmacy, Assiut univ., Assiut 71526, Egypt.
Mojab F., Kmalinejad M., Ghaderi N. and Vahidipour H. (2003). Phytochemical screening of some species of Iranian plants. Iranian Journal of Pharmaceutical Research, 2:77-82.

Okwu D. E. (2004). Phytochemicals and vitamin content of indigenous species of South Eastern Nigeria. J. Sustain Agric. Environ., 6: 30-34.

Pandy B.P.(1982). Taxonomy of angiosperms. "systematic botany". fourth edition, published by S. chand \& Co. Litd., New Delhi - 110055 .

Pessarakli M. (1995). Hand Book of Plant and Plant Physiology. Library of Congress Catalloging in Publication Data. Printed in the USA, Marcel Dekker, Inc. New York, Basel, Hong Kong . 1004 pp.

Polterait O. (1997). Antioxidants and freeradical scavengers of natural origin. Current Org. Chem., 1:415-440.

Rizk A. M. (1986). The Phytochemistry of the Flora of Qatar. Sci. App. Res. Cent. Qatar Univ., King Printed Ltd. London. p:361364.

Romanova D. and vachalkova A. (1999) .Uv spectrometric and DC polrographic studies on apigenin and luteolin. Archives of Pharmacal Research , 22 (2) :173-178.

Sigma (1992). Biochemicals organic compounds for research and diagnostic reagents. Trademark of the Sigma, chemical company. $2176 \mathrm{pp}$.

Sodipo O. A., Akiniyi J. A. and Ogunbamosu J. U. (2000). Studies on certain characteristics of extracts of bark of Pansinystalia macruceras (K schemp) pierre Exbeille. Global J. Pure Appl. Sci., 6: 83-87.

Sofowara A. (1993). Medicinal Plants and Traditional Medicine in Africa $2^{\text {nd }}$ Edn. Spectrum Books Ltd, Ibadan, Nigeria. 289 PP.

Stray F. (1998). The Natural Guide to Medicinal Herbs and Plants. Tiger Book International, London, pp: 12-16.

Watt J. M and Breyer brandoijk M .G. (1962). The medicinal and poisonous plants of southern and eastern Africa. E. and S.lavingstone LTD $2^{\text {nd }}$, lindenberge and London, P.445 -449.

Woo W.S., Chi H.J. and Yun H. S. (1977). Alkaloid screening of some Suadi Arabian plants. Kor. J. Pharmacog. 8 (3) 109-113. 
دراسة مقارنة علي المكونات الكيميائية الفعالة لبعض نباتات العائلة الرمرامية

$$
\text { عاطف السيد أبوزيد }
$$

$$
\text { قسم النباتات الطبية و العطرية ـ مركز بحوث الصحر اء ـ المطرية ـ القاهرة ـ مصر }
$$

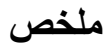

يهدف هذا البحث البي در اسة ومقارنة التركيب الكيميائي للأجز اء الخضرية لبعض نباتـات العائلة الرمر اميـة النامية في

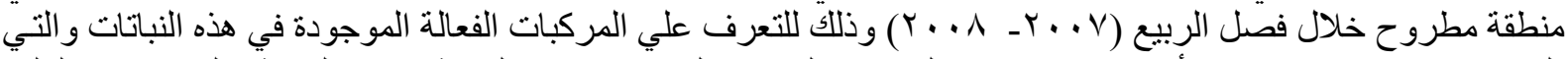

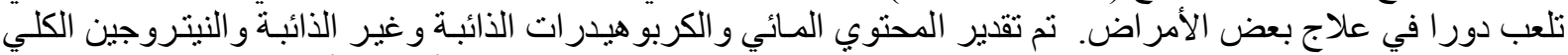

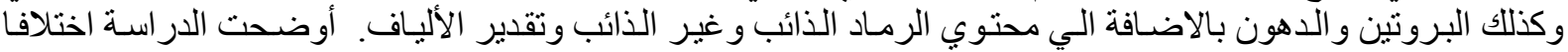

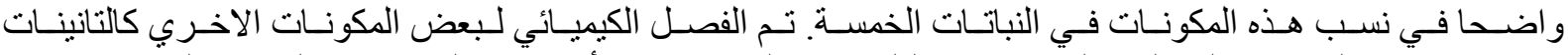

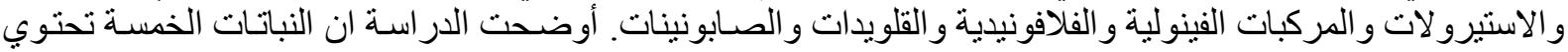

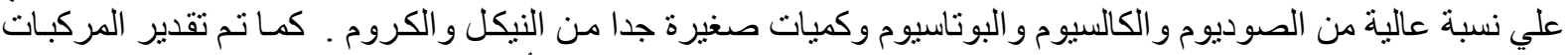

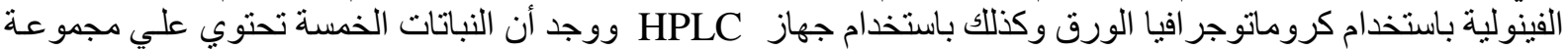

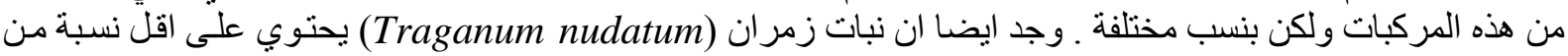

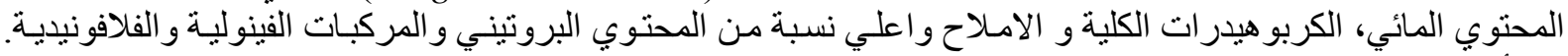

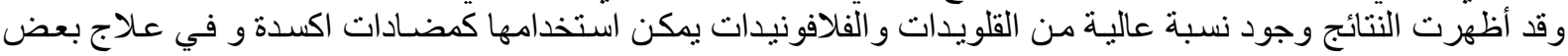

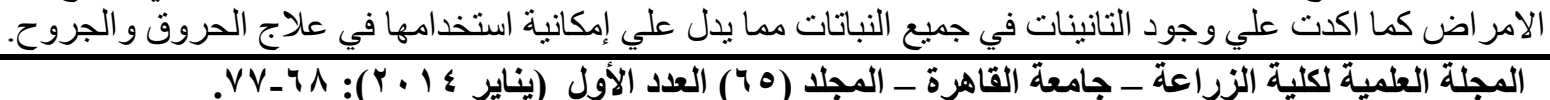

